\section{Pemberdayaan masyarakat Desa Gede \\ Pangrango melalui praktek pekerjaan sosial komunitas}

\author{
Aris Tristanto ${ }^{1}$, Soraya Medina ${ }^{1}$, dan Rendra Restiana ${ }^{1}$
}

Altruis ejournal.umm.ac.id/index.php/altruis 2021, Vol 2(2):37-42 DOI:10.22219/altruis.v2i2.15964 (CThe Author(s) 2021 (ㅇ)(ㅇ) 4.0 International license

\begin{abstract}
This community service activity focuses on efforts to prevent drug abuse in Gedepangrango Village, Kadudampit District, Sukabumi Regency. The selected model of prevention was the prevention that involves all segments of society. The methods and techniques used in this activity refer to community social work practices. From the assessment, it was found that there were three concerns of residents related to drug problems, namely 1) residents wanted to know the characteristics of drug abusers; 2) the types of drugs that are often abused; and 3) how to prevent and handle drug victims. Based on the results of the assessment, the intervention of this activity was carried out in the form of counseling. The main objective of counseling is to provide understanding and awareness to the community regarding drugs, so that the increased understanding can prevent drug abuse in their environment. The main outcome of this activity is the formation of a forum that can shelter the community in dealing with drug problems in Gede Pangrango Village, in this case the forum is the new community-based rehabilitation for victims of drug abusers.
\end{abstract}

\title{
Keywords
}

drugs, social workers, community

\section{Pendahuluan}

Kegiatan pengabdian masyarakat ini merupakan bagian dari kuliah lapangan yang dilaksanakan oleh mahasiswa Program Pendidikan Pascasarjana Spesialis-1 (Sp1) Pekerja Sosial kajian NAPZA. Kegiatan ini merupakan wahana mahasiswa dalam memperoleh pemahaman yang komprehensif tentang setting kajian dan mengimplementasikan berbagai pendekatan atau teknologi yang telah diperoleh pada saat kuliah. Selain itu melalui kegiatan ini, mahasiswa diharapkan dapat memberikan kontribusi kepada masyarakat melalui praktek keilmuannya sehingga pengetahuan masyarakat dapat bertambah.

Lokasi kegiatan yang dipilih oleh mahasiswa Program Pendidikan Pascasarjana Spesialis-1 (Sp-1) Pekerjaan Sosial kajian NAPZA adalah Desa Gede Pangrango, Kecamatan Kadudampit, Kabupaten Sukabumi. Pemilihan lokasi didasari oleh pertimbangan bahwa Desa Gede Pangrango merupakan binaan Desa Sejahtera Mandiri (DSM) dan menjadi tempat praktikum III mahasiswa Diploma IV Pekerjaan Sosial, Politeknik Kesejahteraan Sosial (Poltekesos) Bandung pada tahun 2017.

Dari hasil laporan praktikum III (2017) diketahui bahwa dari sembilan Rukun Warga (RW) yang ada di Desa Gede Pangrango terdapat satu RW yang terindikasi bahwa remajanya sering melakukan penyalahgunaan zat berbahaya. Hal itu disebabkan karena RW tersebut berada pada perlintasan jalan utama desa menuju tempat wisata. Situasi tersebut sejalan dengan pendapat Utari (2017) bahwa daerah pariwisata yang berkembang dengan baik secara tidak langsung berdampak pada peningkatan penyalahgunaan NAPZA di daerah tersebut.

Selain itu dengan banyak penginapan dan villa yang ada mengakibatkan remaja di daerah tersebut mudah terpengaruh dari budaya luar yang dibawa oleh orang-orang atau turis yang menginap. Hal itu tidak dapat dipungkiri karena usia remaja adalah usia yang sangat rentan dengan penyalahgunaan NAPZA, meskipun masalah penyalahgunaan NAPZA ini dapat menyentuh segala kalangan dan usia, namun usia remaja berada dalam tahap masa perkembangan dimana dia mulai mencari jati dirinya, mudah dipengaruhi oleh lingkungan, dan mempunyai rasa keingintahuan yang sangat tinggi (Pinem, 2020).

Kegiatan pengabdian ini berfokus pada upaya pencegahan penyalahgunaan NAPZA. Menurut (Hart et al, 2013) model pencegahan penyalahgunaan NAPZA terbagi atas tiga, yaitu pencegahan primer, pencegahan sekunder, dan pencegahan tersier. Hal tersebut sejalan dengan Peraturan

${ }^{1}$ Poltekesos Bandung

Korespondensi:

Aris Tristanto, Program Pendidikan Pascasarjana Spesialis 1 Pekerja Sosial, Poltekesos Bandung

Email: tristanto29@gmail.com 
Menteri Sosial Republik Indonesia Nomor 26 Tahun 2012 Tentang Standar Rehabilitasi Sosial Korban Penyalahgunaan Narkotika, Psikotropika, dan Zat Adiktif Lainnya, dimana Pasal 8 ayat (1) menjelaskan bahwa pencegahan penyalahgunaan NAPZA meliputi primer, sekunder, dan tersier.

Dalam melakukan upaya pencegahan penyalahgunaan NAPZA, masyarakat dapat mengambil bagian dalam kegiatan tersebut. Hal itu tertuang pada Bab III dalam Undang-Undang Nomor 35 Tahun 2009 tentang Narkotika dan Bab XII dalam Undang-Undang Nomor 5 Tahun 1997 tentang Psikotropika, yaitu mengenai peran serta masyarakat. Melalui peran serta masyarakat diharapkan dapat membantu pemerintah untuk mencegah dan menanggulangi penyalahgunaan dan pemberantasan peredaran gelap NAPZA, serta mengurangi ancaman NAPZA bagi generasi muda bangsa. Program pengabdian ini berusaha untuk meningkatkan partisipasi masyarakat tersebut dalam mengatasi penyalahgunaan NAPZA di tingkat lokal/daerah.

\section{Metode}

Kegiatan pengabdian yang berfokus pada upaya pencegahan penyalahgunaan NAPZA ini dilaksanakan pada tanggal 8 April sampai dengan 12 April 2019 Di Desa Gede Pangrango, Kecamatan Kadudampit, Kabupaten Sukabumi. Mahasiswa Program Pendidikan Pascasarjana Spesialis-1 (SP-1) Pekerjaan Sosial kajian NAPZA memilih upaya pencegahan primer.

Pencegahan primer merupakan upaya pencegahan yang melibatkan seluruh segmen masyarakat (Ife \& Smith, 1995). Dalam hal ini masyarakat diberikan pengetahuan yang lengkap dan utuh akan bahaya penyalahgunaan NAPZA dan pada akhirnya diharapkan masyarakat memiliki kemampuan untuk menolak atau menghindari masalah penyalahgunaan NAPZA yang ada (Ditjen Rehsos, 2005). Kegiatan pencegahan primer dilakukan dengan memberdayakan masyarakat desa melalui tahap pertolongan sosial dalam teknologi pekerja sosial komunitas.

Pemberdayaan masyarakat menurut Undang-Undang Nomor 1 Tahun 2009 tentang Kesejahteraan Sosial (Undang Undang Republik Indonesia, 2009) adalah semua upaya yang diarahkan untuk menjadikan warga negara yang mengalami masalah sosial mempunyai daya, sehingga mampu memenuhi kebutuhan dasarnya. Proses pemberdayaan yang menekankan pada proses memberikan kemampuan kepada masyarakat agar menjadi berdaya, mendorong atau memotivasi individu agar mempunyai kemampuan atau keberdayaan untuk menyelesaikan masalah yang ada.

Dalam melakukan pemberdayaan masyarakat, mahasiswa Program Pendidikan Pascasarjana Spesialis-1 (SP-1) Pekerjaan Sosial kajian NAPZA bermitra dengan berbagai pihak yaitu Kepala Desa Gede Pangrango dan perangkat desa, Bintara Pembina Desa (Babinsa), Tenaga Kesejahteraan Sosial Kecamatan (TKSK), Ketua RW dan para kader desa. Adanya mitra dalam kegiatan ini karena mahasiswa hanya sebagai pendatang sehingga setelah kegiatan selesai akan kembali ke kampus. Maka dari itu dibutuhkan orang-orang yang dapat menjadi motor penggerak dalam masyarakat setelah sekembalinya mahasiswa agar upaya pencegahan NAPZA tetap dapat berjalan.

Proses awal dalam pemberdayaan masyarakat adalah penjajakan. Dalam penjajakan ini mahasiswa mencoba mengenal dan memahami situasi dan kultur masyarakat setempat. Setelah melakukan penjajakan selanjutnya mahasiswa melakukan bimbingan dengan dosen pendamping lapangan. Bimbingan yang dilakukan melingkupi penyusunan teknik dan strategi dalam praktek pekerjaan sosial komunitas yang akan digunakan dalam kegiatan pengabdian. Setelah penjajakan dan bimbingan dilakukan, proses selanjutnya adalah terjun ke masyarakat. Pada saat terjun ke masyarakat, mahasiswa menerapkan enam tahap pertolongan sosial dalam teknologi pekerja sosial komunitas (Yuliani, 2015).

Tahap pertama adalah inisiasi sosial/persiapan sosial. Tujuan dari tahap inisiasi sosial adalah untuk membentuk kesepakatan, menjalin relasi serta kepercayaan antara mahasiswa dan masyarakat sehingga nantinya memudahkan mahasiswa untuk memperoleh akses yang dibutuhkan selama kegiatan dilaksanakan (Adi, 2008). Tahap kedua adalah asesmen sosial. Tahap ini merupakan pemahaman dan pengungkapan masalah melalui kegiatan pengumpulan dan analisa data ke dalam satu formulasi (Siporin, 1975; Rothman \& Tropman, 1987).

Setelah tahap asesmen sosial dilakukan, tahap ketiga adalah rencana intervensi. Menurut Stepney (2010) rencana intervensi adalah hal yang tidak terpisahkan dari proses asesmen. Setelah menyusun rencana intervensi, tahap keempat adalah intervensi. Dalam praktik pekerjaan sosial, intervensi adalah tindakan spesifik oleh seorang pekerja dalam kaitan dengan sistem dan proses manusia untuk menimbulkan perubahan ke arah yang lebih baik. Tindakan ini diarahkan oleh pengetahuan dan nilai-nilai profesional serta keterampilan (tingkat kompetensi) dari pekerja sosial (Alamsyah, 2015). Intervensi yang dipilih dalam hal ini adalah penyuluhan tentang NAPZA.

Tujuan utama dari penyuluhan adalah untuk memberikan pemahaman dan kesadaran kepada masyarakat terkait masalah NAPZA, sehingga dengan meningkatnya pemahaman masyarakat, maka diharapkan masyarakat dapat berperan aktif dalam melakukan pencegahan penyalahgunaan NAPZA di lingkungannya. Kegiatan penyuluhan ini dilakukan pada tanggal 10 April 2019. Lokasi yang digunakan untuk melakukan penyuluhan adalah ruang kelas kober Kecipir RW 02. Jumlah peserta yang datang dalam penyuluhan adalah sebanyak 22 orang yang berasal dari berbagai unsur masyarakat. Materi dalam penyuluhan ini terbagi menjadi tiga yaitu bentuk NAPZA dan dampaknya, ciri-ciri penyalahguna NAPZA, serta jejaring kerja dalam pencegahan penyalahgunaan NAPZA. Penyuluhan ini dibuka oleh dosen Poltekesos Bandung yaitu Lina Favourita Setiaputri, M.Si, Ph.D. 
Sebelum kegiatan penyuluhan dilakukan maka 22 orang peserta penyuluhan terlebih dahulu diberikan pretest berupa soal yang terkait dengan materi penyuluhan. Setelah penyuluhan dilakukan peserta penyuluhan kembali diberi soal dalam bentuk post test.

Tahap kelima dalam proses pertolongan pekerjaan sosial komunitas adalah monitoring dan evaluasi. Menurut Sukoco (2011), monitoring dan evaluasi terhadap proses kegiatan dilakukan setelah kegiatan dilakukan baik itu pada saat asesmen dan penyusunan intervensi maupun pada saat intervensi. Tahap terakhir adalah terminasi dan rujukan, yang merupakan tahapan pengakhiran dari semua kegiatan proses pertolongan pekerjaan sosial komunitas.

\section{Hasil}

Metode dan teknik dalam praktek pekerjaan sosial komunitas dalam kegiatan ini berfokus pada upaya pencegahan penyalahgunaan NAPZA. Upaya ini dilakukan dengan menerapkan enam tahap pertolongan sosial dalam teknologi pekerja sosial komunitas dengan langkah mulai dari inisiasi sosial hingga intervensi.

\section{Inisiasi sosial/persiapan sosial}

Pada dasarnya tahap inisiasi sosial ini merupakan tahapan yang tidak ada henti-hentinya sampai ditetapkannya bahwa proses pertolongan sudah selesai (Jeffries, 1996). Pada tahap ini dilakukan kunjungan ke rumah masyarakat dan tokoh masyarakat. Kegiatan ditujukan untuk mengenal masyarakat desa dan tokoh masyarakat yang menjadi sumber utama informasi (key people). Kegiatan ini sangat efektif dan dapat memperoleh dukungan dari masyarakat dan tokoh masyarakat sehingga memudahkan mahasiswa untuk melakukan kegiatan pertolongan pekerjaan sosial segi komunitas.

Inisiasi sosial diawali dengan Transect Walk. Tujuan kegiatan ini untuk melakukan pengamatan langsung lingkungan dan sumberdaya masyarakat, selain itu juga untuk memperkenalkan diri dan menjelaskan maksud serta tujuan kegiatan yang dilakukan mahasiswa pada masyarakat di setiap RW.

Berikutnya dilakukan diskusi informal dengan TKSK, Babinsa dan Kepala Dusun. Diskusi informal ini dilakukan pada saat kegiatan penerimaan mahasiswa di kantor desa. Tujuan dilakukan diskusi ini adalah untuk mengetahui program-program dan kebijakan yang ada di desa terkait dengan penanganan masalah NAPZA. Teknik pengumpulan data dilakukan dengan cara wawancara.

Setelah mahasiswa Program Pendidikan Pascasarjana Spesialis-1 (SP-1) Pekerjaan Sosial kajian NAPZA melaksanakan tahap inisiasi dalam proses pertolongan pekerjaan sosial komunitas, tahap selanjutnya yang dilakukan oleh mahasiswa adalah asesmen sosial.

\section{Asesmen sosial}

Dalam asesmen sosial, hal yang penting untuk ditemukan adalah lima dimensi vital yaitu: 1) sifat permasalahan masyarakat, termasuk perhatian khusus terhadap peran-peran masyarakat dan hal penting lainnya yang sulit dijalankan; 2) keberfungsian masyarakat (kekuatan, potensi, keterbatasan, dan kekurangannya) serta hal penting lainnya; 3) motivasi masyarakat dalam mengatasi masalah; 4) relevansi faktor lingkungan yang turut mendukung timbulnya masalah; dan 5) sumber-sumber yang yang tersedia atau dibutuhkan untuk mengurangi atau menghilangkan kesulitan masyarakat (Yuliani, 2015).

Teknologi yang digunakan pada tahap asesmen sosial adalah Methodology Participatory Assessment (MPA). Tujuan dari implementasi teknologi MPA adalah untuk menemukenali dan menggali masalah, kebutuhan dan kekuatan masyarakat secara partisipatif (Widiowati et al., 2014). Bentuk kegiatan ini adalah rembug warga. Sasaran kegiatan ini adalah masyarakat terutama kalangan remaja dan para kader desa yang peduli pada masalah penanggulangan NAPZA.

Terdapat beberapa langkah-langkah MPA yang dilaksanakan. Mulanya seluruh peserta pertemuan diminta untuk menuliskan kebutuhan dan masalah mengenai NAPZA pada meta card. Satu meta card mewakili satu jenis kebutuhan dan masalah. Kebutuhan dan masalah yang sudah ditulis kemudian ditempel di kertas plano yang sudah disediakan. Meta card yang sudah ditempel kemudian dikelompokkan sesuai dengan kebutuhan dan masalah yang sejenis (Cluster). Kemudian, setiap kelompok kebutuhan dan masalah diberi judul (titel). Titel tersebut harus merangkum semua jenis kebutuhan dan masalah yang ada di kelompoknya. Adapun jumlah titel yang teridentifikasi menunjukkan jumlah dan jenis masalah yang ada di lingkungan masyarakat tersebut. Prioritas masalah tidak melihat dari jumlah meta card yang ada masalah tersebut tetapi berdasarkan hasil rembug bersama dengan para peserta.

Dalam rembug warga yang dilakukan oleh mahasiswa bersama dengan perwakilan masyarakat ditemukan berbagai masalah sosial di Desa Gede Pangrango. Masalah itu diantaranya adalah banyaknya anak remaja berkumpul di pada malam tampa kegiatan yang jelas dan bermanfaat, terlihat anak-anak SMA berseragam sering kumpul dan merokok di sekitar gang baik itu siang maupun sore hari, ditemukan bekas minuman keras di lingkungan desa, dan wisatawan sering berpesta pada malam hari.

Pada tahap penentuan prioritas masalah, peneliti menggunakan teknis penskoran dengan meminta masyarakat voting melalui tunjuk tangan. Kemudian peneliti menghitung hasil voting tersebut dan memberi skor tertulis pada kertas plano. Dari hasil penskoran yang kemudian di rekapitulasi maka ditemukan permasalahan yang memiliki nilai skor terbesar (bekas minuman keras) dan terkecil (wisatawan berpesta di malam hari) dengan anak-anak 
merokok sebagai masalah prioritas kedua dan anak-anak nongkrong di malam hari sebagai masalah prioritas ketiga.

Hasil voting ini kemudian didiskusikan kembali dengan peserta untuk mengkonfirmasi secara mufakat permasalahan yang menjadi prioritas. Dari hasil diskusi lanjutan maka diketahui bahwa kenapa warga menjadikan hal tersebut sebagai prioritas karena warga telah merasa resah dengan banyaknya sampah miras di lingkungan mereka. Berdasarkan hal tersebut maka timbul kebutuhan dari warga untuk menyelesaikan masalah tersebut. Kebutuhan tersebut yaitu warga ingin mengetahui ciri-ciri pengguna, jenis-jenis NAPZA yang sering disalahgunakan serta cara pencegahan dan penanganan korban NAPZA.

\section{Intervensi}

Mengingat efektifitas waktu kegiatan maka setelah diperoleh gambaran kebutuhan dan masalah yang dirasakan bersama oleh masyarakat, mahasiswa memandu warga untuk mendiskusikan penyelesaian dari masalah yang ada dan hal atau kegiatan apa yang sekiranya dapat dilakukan dalam waktu dekat agar masalah tersebut bisa terselesaikan. Setelah didiskusikan maka peserta memutuskan untuk mengadakan sebuah penyuluhan terkait masalah NAPZA. Pada akhir proses rencana intervensi mahasiswa dan peserta yang hadir sepakat membuat janji untuk menyukseskan rencana yang telah disusun.

Kegiatan intervensi dimulai dengan melakukan persiapan di lokasi yang akan digunakan untuk melakukan penyuluhan tentang penyalahgunaan NAPZA. Selanjutnya, mahasiswa melakukan kegiatan penyuluhan tentang masalah penyalahgunaan NAPZA. Kegiatan penyuluhan diikuti oleh masyarakat setempat baik itu bapak-bapak dan ibu-ibu, remaja serta para kader PKK yang peduli dan konsen pada masalah penanggulangan NAPZA.

Kegiatan penyuluhan ini juga diselingi dengan pretest dan post test kepada para peserta. Tujuan pretest dan post test dalam penyuluhan ini adalah untuk mengetahui sejauh mana keberhasilan dari penyuluhan yang telah disampaikan. Dari hasil penilaian ditemukan bahwa dari 22 orang yang mendapatkan penyuluhan hanya 12 orang yang mengalami peningkatan skor. Sedangkan, lima orang lainnya tidak ada perubahan dan lima orang sisanya malah menurun skornya. Hal tersebut dapat disebabkan oleh kognitif setiap orang berbeda dimana tidak semua aktivitas mental seseorang dalam memperoleh pengetahuan dan memecahkan masalah dapat dilakukan dengan waktu cepat dan mudah. Selain itu kognitif ini dipengaruhi oleh faktor: 1) materi yang disampaikan sama dengan pengetahuan yang sudah dimiliki dan susah untuk diubah; 2) waktu penyuluhan; 3) pelaksanaan penyuluhan; 4) alat peraga dalam penyuluhan.

Setelah kegiatan penyuluhan, maka timbul kesadaran dari masyarakat untuk membentuk suatu wadah yang dapat menaungi masyarakat dalam menangani permasalahan NAPZA di Desa Gede Pangrango. Hal tersebut dipilih karena kurangnya pemahaman masyarakat terhadap
NAPZA dan belum ada wadah yang dapat menaungi masalah NAPZA. Wadah yang dimaksud adalah Rehabilitasi Berbasis Masyarakat (RBM) untuk korban penyalahguna NAPZA.

Menurut Direktorat Rehabilitasi Sosial Korban Penyalahgunaan NAPZA (2015) rehabilitasi berbasis masyarakat merupakan salah satu strategi dalam perluasan jangkauan pelayanan masyarakat yang menempatkan masyarakat sebagai basis utama pelaku pelayanan. Masyarakat akan memiliki otoritas yang nyata dan tanggungjawab untuk mengelola layanan-layanan dengan cara yang paling sesuai dengan keadaan mereka (Netting et al., 1993). Masyarakat lokal dapat menetapkan prioritas mereka sendiri dimana kontribusi dari semua anggota masyarakat akan dihargai dan didorong (Hikmat, 2001). Sedangkan menurut Marbun \& Ismudiyanti (2015) rehabilitasi berbasis masyarakat merupakan wadah masyarakat lokal yang berfungsi sebagai alat penyadaran masyarakat sehingga lebih menyentuh dan dapat dipandang sebagai salah satu strategi dalam mengikis stigma di masyarakat terkait mantan penyalahguna NAPZA, sebagai penjangkauan pelayanan di lingkungannya yang selama ini masih tersembunyi.

Keberhasilan penyelenggaraan RBM sangat ditentukan oleh seberapa besar partisipasi masyarakat. Menurut Clark (1995) salah satu syarat utama terjadinya pembangunan berkelanjutan adalah menjamin efektivitas partisipasi dalam pengambilan keputusan. Sedangkan menurut Gunawan (2018) mengemukakan bahwa setiap warga masyarakat harus berpartisipasi secara aktif di dalam upaya perubahan masyarakat dimana partisipasi warga masyarakat itu haruslah seluas mungkin dan dilaksanakan melalui organisasi-organisasi yang demokratis.

\section{Monitoring dan evaluasi}

Monitoring kegiatan dilaksanakan secara berkala dilakukan oleh mahasiswa bersama dengan dosen pendamping lapangan. Tujuan dari kegiatan ini adalah untuk melihat progress pencapaian kegiatan pemberdayaan melalui proses pertolongan pekerjaan sosial komunitas. Selain itu monitoring juga dilakukan untuk memperbaiki langkah-langkah kegiatan yang belum terealisasi sesuai rencana agar selanjutnya langkah-langkah kegiatan tepat sasaran. Monitoring pada kegiatan ini dilaksanakan secara kualitatif dengan tujuan untuk menilai tahap-tahap kegiatan, sesuai tidaknya kegiatan yang dilakukan dengan rencana yang ditetapkan, dan tepat tidaknya program yang dilaksanakan dalam setiap tahap kegiatan dengan perencanaan kegiatan yang ditetapkan.

Proses Evaluasi merupakan aktivitas yang dilakukan untuk mengetahui proses dan hasil yang dicapai dalam suatu program. Kegiatan evaluasi dilakukan dengan memberikan penilaian secara kualitatif terkait pelaksanaan kegiatan yang telah dilaksanakan. Evaluasi dilakukan mahasiswa bersama dengan mitra terkait. Kegiatan 
dilaksanakan pada tanggal 11 April 2019 bertempat di kantor desa.

Evaluasi dalam kegiatan ini terbagi menjadi proses dan hasil kegiatan dimana evaluasi dilakukan dengan cara penilai terbuka. Teknik yang digunakan dalam penilaian terbuka adalah melalui diskusi dimana partisipan diminta untuk memberikan tanggapan dan masukan terhadap masing-masing tahapan kegiatan yang dilaksanakan.

Berdasarkan hasil evaluasi maka diketahui bahwa proses kegiatan sangat baik. Hal tersebut karena persiapan kegiatan sangat mantang, pernyataan pemahaman masalah sangat tepat, perencanaan pemecahan masalah sesuai dengan situasi yang ada, serta pelaksanaan kegiatan berjalan sesuai dengan harapan. Terkait dengan hasil kegiatan menurut hasil evaluasi adalah bagus karena antusias warga dan anggota kelompok mengikuti kegiatan sangat tinggi, adanya terjadi pertukaran informasi sehingga terjadi peningkatan kapasitas.

\section{Terminasi dan rujukan}

Terminasi dan rujukan merupakan kegiatan terakhir dari tahap pertolongan sosial dalam teknologi pekerja sosial komunitas. Terminasi dilakukan hari Selasa, 12 April 2019. Kegiatan terminasi yang dilakukan antara lain pelaporan hasil kegiatan-kegiatan yang telah dilakukan kepada aparat desa. Selanjutnya mahasiswa melakukan rujukan desa dan mitra terkait dengan memberikan cacatan-catatan tentang list kegiatan yang harus ditindaklanjuti dalam waktu dekat seperti pembentukan RBM NAPZA.

\section{Kesimpulan}

Kegiatan pengabdian ini dilaksanakan di Desa Gede Pangrango, Kecamatan Kadudampit, Kabupaten Sukabumi. Kegiatan ini berfokus pada upaya pencegahan penyalahgunaan NAPZA dengan cara melakukan pemberdayaan kepada masyarakat. Melalui kegiatan pemberdayaan masyarakat, program ini secara tidak langsung memberikan kebebasan kepada masyarakat untuk ikut berpartisipasi dalam proses pencegahan penyalahgunaan NAPZA di lingkungannya. Adanya partisipasi masyarakat tersebut mempercepat upaya pencegahan penyalahgunaan NAPZA karena masyarakat lebih mengetahui situasi dan kondisi lingkungannya. Setelah kegiatan penyuluhan, timbul kesadaran dari masyarakat untuk membentuk suatu wadah yang dapat menaungi masyarakat dalam menangani permasalahan NAPZA di Desa Gede Pangrango.

Kegiatan pengabdian ini tidak dapat digeneralisasikan dan tidak dapat langsung diterapkan di tempat lain secara keseluruhan. Hal tersebut disebabkan karena aspek sosial-budaya di setiap daerah berbeda. Selain itu, situasi dan permasalahan sosial NAPZA pada dasarnya tidak stabil, maka sulit mengukur konsistensi hasil kegiatan pada waktu dan tempat yang berbeda. Oleh sebab itu penulis menyarankan kepada pembaca yang akan melakukan kegiatan pengabdian terkait masalah NAPZA maka penting untuk mempertimbangkan aspek sosial budaya ditempat kegiatan karena aspek sosial-budaya sangat menentukan keberhasilan kegiatan.

\section{Referensi}

Adi, I.R. (2008). Intervensi Komunitas, Konsep dan Implementasinya. Jakarta: UI Pres

Alamsyah, C. Y. (2015). Praktik Pekerjaan Sosial Generalis: Suatu Tuntutan Intervensi. Yogyakarta: Pustaka Pelajar.

Clark, J. (1995). NGO dan Pembangunan Demokrasi, (Judul asli: Democratizing Development the Role Of Voluntary Organization: Godril Dibyo Yuono). Yogyakarta: Tiara Wacana,

Direktorat Rehabilitasi Sosial Korban Penyalahgunaan NAPZA. (2015). Pedoman Intervensi Komunitas melalui Penguatan Keluarga oleh Kelompok Pendampingan Rehabilitasi Sosial Berbasis Masyarakat bagi Korban Penyalahgunaan NAPZA. Jakarta: Kementerian Sosial RI

Ditjen Rehsos. (2005). Modul Standar Indikatif Pencegahan Penyalahgunaan NAPZA. Jakarta: Departemen Sosial RI

Gilbert, N. (1977). Planning for Social Welfare; Issues, Models and Taks. Prentice-Hall Inc.

Gunawan, N. F. N. (2018). Rehabilitasi Sosial Berbasis Masyarakat Bagi Korban Penyalahgunaan NAPZA. Sosio Konsepsia, 6(1), 18-38.

Hart, C. L., Ksir, C., \& Ray, O. S. (2013). Drugs, society \& human behavior. New York, NY: McGraw-Hill.

Hikmat, H. (2001). Strategi Pemberdayaan Masyarakat. Bandung: Humaniora Utama.

Ife, J. W., \& Smith, M. (1995). Community development: Creating community alternatives-vision, analysis and practice (pp. 1-3). Melbourne: longman.

Jeffries, A. (1996). Modelling community work: An analytic framework for practice. Journal of Community Practice, 3(34), 101-125.

Laporan Praktikum III. (2017). Permasalahan Sosial, Pontensi dan Sumber. Bandung: STKS

Marbun, J., \& Ismudiyati, Y.S. (2015). Manual Kajian Pekerjaan Sosial dengan NAPZA. Bandung: Program Pascasarjana Spesialis-1 STKS Bandung.

Netting, F. Ellen, Peter M. Kettner dan Steven L. McMurtry (1993), Social Work Macro Practice. New York: Longman.

Pemerintah Republik Indonesia (1999). Undang-Undang Nomor 5 Tahun 1997 Tentang Psikotropika. Jakarta.

Pemerintah Republik Indonesia (2009). Undang-Undang Nomor 1 Tahun 2009 Tentang Kesejahteraan Sosial. Jakarta.

Pemerintah Republik Indonesia (2009).Undang-Undang Nomor 35 Tahun 2009 Tentang Narkotika. Jakarta.

Peraturan Menteri Sosial Republik Indonesia Nomor 26 Tahun 2012 Tentang Standar Rehabilitasi Sosial Korban Penyalahgunaan Narkotika, Psikotropika, Dan Zat Adiktif Lainnya.

Pinem, M. Y. (2020). Tinjauan Kriminologi Terhadap Kejahatan Yang Timbul Akibat Dari Penyalahgunaan Narkoba Di Kalangan Anak Bawah Umur (Doctoral dissertation). 


\section{Medan: UMSU}

Rothman, J., \& Tropman, J. E. (1987). Models of community organization and macro practice perspectives: Their mixing and phasing. Strategies of community organization, 4, 3-26.

Siporin, M. (1975). Introduction to Social Work Practice. Macmillan Publishing Co: New York

Stepney, P. (2010). Social welfare at the crossroads: Evidencebased practice or critical practice? International Journal of Interdisciplinary Social Sciences, 5(5).
Sukoco, D.H. (2011). Profesi Pekerjaan Sosial dan Proses Pertolongannya. Bandung: STKSPress

Widiowati, D., Rustanto, B., Yuliani, D., \& Kartika, T. (2014) Modul Pendekatan dan Teknologi Komunitas. Bandung: Program Pascasarjana Spesialis-1 STKS.

Yuliani, D. (2015). Modul Pendekatan dan Teknologi Pekerjaan Sosial Komunitas. Bandung: Program Pascasarjana Spesialis-1 STKS. 